\title{
EVALUASI PENGGUNAAN ANTIBIOTIKA BERDASARKAN METODE DEFINED DAILY DOSE (DDD) PADA PASIEN ULKUS DIABETIKUM
}

\author{
Adiyat Edy Wahyudi ${ }^{1, *}$, Jaka Fadraersada², Muhammad Amir Masruhim ${ }^{1}$ \\ ${ }^{1}$ Laboratorium Penelitian dan Pengembangan Kefarmasian "Farmaka Tropis", \\ Fakultas Farmasi, Universitas Mulawarman, Samarinda, Indonesia \\ ${ }^{2}$ Kelompok Bidang Ilmu Farmasi Klinik dan Komunitas, Fakultas Farmasi, \\ Universitas Mulawarman, Samarinda, Indonesia \\ *Email: adiyatrwi@gmail.com
}

\begin{abstract}
The impacts of irrational use of antibiotics on patients with diabetic foot ulcers are increases incidence of resistance, the occurrence of drug side effects, failure of therapy, the disease experienced by patients worsens and thus decreases the quality of health services. The purpose of this study was to calculate DDD values to determine the rational level of antibiotic use in diabetic ulcer patients receiving antibiotic therapy. This study used a retrospective observational design and quantitative descriptive data acquisition using DDD calculations. Quantitative assessment was carried out using the ATC / DDD method and $90 \%$ DU. The evaluation results of antibiotic use on the total number of DDD / 100 patient-days values showed the highest value of Ceftriaxone at 31.88 DDD / 100 days of care, followed by metronidazole at 10.87 DDD / 100 days of care, meropenem at 7.06 DDD / 100 day of care, Ciprofloxacin 5,07DDD/ 100 Days of care, Amikacin 1.63 DDD / 100 days of care and Sefoperazone at 1.45DDD / 100 days of care. With 3 types of antibiotics that include in the DU segment $90 \%$ of the most use are ceftriaxone $64.59 \%$, metronidazole 17.76, meropenem 7.28\%. and ciprofloxacin 6,01\%. The result shows that the quantity of antibiotics used does not indicate the principle of rational use of antibiotics.
\end{abstract}

Keywords: Antibiotics, ATC, Defined Daily Dose (DDD), DU 90\%, Diabetic foot ulcer

\begin{abstract}
ABSTRAK
Dampak penggunaan antibiotika yang tidak rasional pada pasien Ulkus kaki diabetik yaitu meningkatnya kejadian resistensi, kejadian efek samping obat, terjadi kegagalan terapi, penyakit yang dialami pasien bertambah parah sehingga menurunkan kualitas pelayanan kesehatan. Tujuan penelitian ini adalah untuk menghitung nilai DDD untuk mengetahui tingkat rasional penggunaan antibiotika pada pasien ulkus diabetikum yang menerima terapi antibiotika. Penelitian ini menggunakan rancangan observasional retrospektif dan perolehan data secara deskriptif kuantitatif mengunakan perhitungan DDD. Penilaian secara kuantitatif dilakukan dengan metode ATC/DDD dan DU 90\%. Hasil evaluasi penggunaan antibiotik pada jumlah keseluruhan nilai DDD/100 patient-days didapatkan nilai tertinggi yaitu Ceftriaxone sebesar 31,88 DDD/100 hari rawat, diikuti dengan metronidazol sebesar 10,87 DDD/100 hari rawat, meropenem sebesar 7,06 DDD/100 hari
\end{abstract}


rawat, Amikacin 1.63 DDD/100 hari rawat dan Sefoperazone sebesar 1,45DDD/100 hari rawat. Dengan 3 jenis antibiotik yang masuk ke dalam segmen DU 90\% penggunaan terbanyak yaitu seftriakson 64,59\%, metronidazol 17,76\%, meropenem 7,28\% dan ciprofloxacin $6,01 \%$. Hal ini menunjukkan bahwa kuantitas antibiotik yang digunakan tidak menunjukkan prinsip penggunaan antibiotik yang rasional.

Kata kunci : Antibiotik, ATC, Defined Daily Dose (DDD), , DU 90\%, Ulkus kaki diabetik

DOI: https://doi.org/10.25026/mpc.v8i1.298

\section{PENDAHULUAN}

Penyakit infeksi masih merupakan masalah kesehatan bagi masyarakat Indonesia maupun negara berkembang lainnya. ${ }^{1}$ Ulkus kaki diabetik sampai saat ini menjadi masalah kesehatan utama di seluruh dunia, karena kasus yang semakin meningkat, ulkus bersifat kronis dan sulit sembuh, mengalami infeksi dan iskemia tungkai dengan risiko amputasi bahkan mengancam jiwa, membutuhkan sumber daya kesehatan yang besar, sehingga memberi beban sosio-ekonomi bagi pasien, masyarakat, dan negara. Berbagai metode pengobatan telah dikembangkan namun sampai saat ini belum memberikan hasil yang memuaskan. Peningkatan populasi penderita diabetes mellitus (DM), berdampak pada peningkatan kejadian ulkus kaki diabetik sebagai komplikasi kronis DM, dimana sebanyak $15-25 \%$ penderita DM akan mengalami ulkus kaki diabetik di dalam hidup mereka. ${ }^{2}$

Di Amerika Serikat, Huang dkk. (2009) memproyeksikan jumlah penyandang DM dalam 25 tahun ke depan (antara tahun 2009-2034) akan meningkat 2 kali lipat dari 23,7 juta menjadi 44,1 juta, biaya perawatan per tahun meningkat sebanyak 223 miliar dolar dari 113 menjadi 336 miliar dolar Amerika Serikat. Biaya pengobatan DM dan komplikasinya pada tahun 2007 di Amerika Serikat mencapai 116 miliar dolar, dimana $33 \%$ dari biaya tersebut berkaitan dengan pengobatan ulkus kaki diabetik. $^{3}$

Kuantitas penggunaan antibiotik menurut perhitungan metode ATC/DDD didapatkan hasil pada tahun 2004 105,2 DDD/100 hari rawat dan tahun 2006 107,3 DDD/100 hari rawat. Sistem ATC/DDD (ATC $=$ Anatomical Therapeutic Chemical, DDD = Defined Daily Dose) adalah sistem klasifikasi dan pengukuran penggunaan obat yang saat ini menjadi salah satu pusat perhatian dalam pengembangan penelitian penggunaan obat. ${ }^{4}$

Hasil evaluasi penggunaan obat dapat dibandingkan dengan menggunakan metode ATC/DDD. Adanya perbandingan penggunaan obat ditempat berbeda sangat bermanfaat untuk menemukan adanya perbedaan substansial yang akan menuntun untuk dilakukan evaluasi lebih lanjut jika ditemukan perbedaan yang bermakna, yang akhirnya akan mengarahkan pada identifikasi masalah dan perbaikan sistem penggunaan obat. 5

\section{METODOLOGI}

Metode penelitian dilakukan secara observational dengan cara retrospektif yaitu dengan melakukan penelusuran dokumen terdahulu yaitu rekam medik pada pasien ulkus diabetikum yang menerima terapi antibiotika di RS Samarinda Medika Citra dengan metode Defined Daily Dose (DDD). 


\section{Metode Sampling}

Teknik pengambilan sampel dalam penelitian ini adalah consecutive sampling. Pada consecutive sampling, semua subjek yang datang dan memenuhi kriteria pemilihan dimasukkan dalam penelitian sampai jumlah subjek yang diperlukan terpenuhi. Consecutive sampling ini merupakan jenis nonprobability sampling yang paling baik, dan merupakan cara termudah. Sebagian besar penelitian klinis (termasuk uji klinis) menggunakan teknik ini untuk pemilihan subjeknya. ${ }^{5}$

\section{Subjek Penelitian}

Kriterian Inklusi

a. Pasien ulkus diabetik yang sudah terdiagnosis ulkus kaki diabetik oleh dokter

b.

c. Pasien ulkus diabetik dari tahun 2017

d. Pasien ulkus diabteik yang dirawat di ruang rawat inap.

\section{Teknik Pengambilan Data}

Tahap pengambilan data diambil dari data rekam medik yang meliputi nomor rekam medik, jenis kelamin, data laboratorium, jenis dan golongan antibiotika, dosis, frekuensi dan jumlah hari rawat inap pasien, riwayat pengobatan lain selama menjalani terapi antibiotika di RS. Samarinda Medika Citra. Dalam tahap ini akan dilakukan penyeleksian data yaitu berdasarkan kriteria inklusi dan eksklusi. Kemudian dilakukan pencatatan data, pada tahap ini peneliti mencatat data pasien ulkus diabetikum yang menjalani rawat inap di RS. Samarinda Medika Citra dan menerima terapi antibiotika. Pencatatan data menggunakan instrumen penelitian yaitu lembar data pasien.

\section{Teknik Analisis Data}

Proses pengambilan data dilakukan di Rumah Sakit Samarinda Medika Citra berupa data rekam medik yang telah dilakukan pemilihan berdasarkan kriteria inklusi yang nantinya diolah menggunakan metode Defined Daily Dose (DDD) dan Kode ATC berdasarkan WHO.

\section{HASIL DAN PEMBAHASAN}

Penelitian ini dilakukan dengan mengambil data rekam medik pasien ulkus diabetik di Rumah Sakit Samarinda Medika Citra. Data pasien yang digunakan adalah pasien ulkus diabetik yang berobat rawat inap di Rumah Sakit Samarinda Medika Citra. Pengambilan sampel dilakukan melalui metode Consecutive Sampling hingga dari 100 data rekam medis yang diberikan Tim Rekam Medis Rumah Sakit Samarinda Medika Citra, didapatkan 59 data yang terdiagnosis ulkus diabetik sedangkan 41 data lainnya di eksklusi karena tidak memenuhi kriteria inklusi.

Untuk distribusi kasus ulkus diabetik di Rumah Sakit Samarinda Medika Citra berdasarkan kelompok Usia (Depkes) didapatkan usia dewasa (26-45 tahun) 10 pasien atau $16,9 \%$, kelompok usia lansia (46-65 tahun) 45 pasien atau $76,3 \%$ dan kelompok usia manula (> 65 tahun) 4 pasien atua 6,8 \% .

Dari gambaran ini, didapatkan kelompok usia tertinggi yakni kelompok usia lansia yang berkisar antara 46-65 tahun dengan rata-rata usia 53,9 tahun. Hal ini sesuai dengan penelitian Madanchi dkk. dan Lianes dkk. yang menyatakan bahwa puncak pasien ulkus diabetik berada di dekade ke 5 dan ke 6 kehidupan. Tidak hanya itu, Mandachi dkk. dalam penelitiannya juga menguraikan bahwa dalam penelitian lain yang ditemukan didapatkan juga rerata usia pasien berkisar antara 55-60 tahun. Chomi dkk., Raymundo Mendoza dkk dan Decroli dkk juga menyatakan dalam penelitiannya bahwa pasien ulkus diabetik terbanyak masing-masing berada pada kelompok usia 50-59 tahun dengan rata-rata masing-masing 53 tahun, kelompok usai 40-59 tahun dengan rata- 
rata 55,2 $\pm 9,5$ tahun dan kelompok usia 51-60 tahun dengan rata-rata usia pasien $56+28.2$ tahun.

Hal ini kemungkinan terjadi karena pada pasien tua telah terjadi penurunan respon inflamasi, penurunan kemampuan poliferasi sel, perlambatan angiogenesis dan memiliki laju sintesis kolagen yang lebih rendah dibandingkan dengan degradasinya. ${ }^{6}$

Tabel 1. Karakteristik Usia Pasien Ulkus Diabetikum

\begin{tabular}{cccc}
\hline Variabel & & Jumlah $(\mathrm{n}=59)$ & Persentase $(\%)$ \\
\hline Usia & Dewasa & 10 & 16.9 \\
& Lansia & 45 & 76.3 \\
& Manula & 4 & 6.8 \\
\hline
\end{tabular}

Tabel 2. Karakteristik Pemberian Antibiotik Pasien Ulkus Diabetik

\begin{tabular}{ccc}
\hline Variabel Antibiotik & Jumlah $(\mathrm{n}=59)$ & Presentase (\%) \\
\hline Derivat beta laktam : & 11 & 18,6 \\
-Sefalosforin generasi 3 & 1 & 1,7 \\
-Karbapenem & & 1,7 \\
Kuinolon & 1 & 3,4 \\
Sefalosporin + karbapenem & 2 & 3,4 \\
Sefalosporin + kuinolon & 2 & 1,7 \\
Sefalosporin + sulbaktam & 1 & 49,2 \\
Sefalosporin + amubisid & 29 & 3,4 \\
Sefalosporin + karbapenem + sulbaktam & 2 & 3,4 \\
Sefalosporin + amubisid + kuinolon & 2 & 1,7 \\
Sefalosporin + kuinolon + karbapenem & 1 & 1,7 \\
Sefalosporin + amubisid + karbapenem & 1 & 1,7 \\
Sefalosporin + amubisid + aminoglikosida & 1 & 3,4 \\
Kuinolon + amubisid + karbapenem & 2 & 1,7 \\
Sefalosporin + kuinolon + karbapenem + amubisid & 1 & 1,7 \\
Sefalosporin + karbapenem + sulbaktam + amubisid & 1 & \\
\hline
\end{tabular}

Berdasarkan tabel di atas, diketahui bahwa pemberian antibiotik pada pasien ulkus diabetik di Rumah Sakit Samarinda Medika Citra dapat meliputi monoterapi antibiotik seperti dari derivat beta laktam sefalosporin generasi ke-3 seperti seftizoksim, sefoperazon, seftriakson, sefiksim, seftizidim dan sefuroksim (18.6\%) Dari distribusi pemberian antibiotik yang telah diuraikan, maka didapatkan bahwa pemberian antibiotik terbanyak pasien ulkus diabetik jatuh pada kombinasi antibiotik antara golongan sefalosporin dengan amubisid yakni sebesar 49,2\% dan distribusi monoterapi sefalosporin generasi ke-3 sebesar 18,6\%. Anggriawan (2014) melaporkan terdapat bakteri aerob dan anaerob dalam kultur pus penderita diabetes, yaitu Enterobacter sp. $(10,71 \%), \quad$ Staphylococcus aureus $(17,85 \%)$, Salmonella sp. $(82,15 \%)$ dan Pseudomonas sp $(17,86 \%)^{7}$

Pada penggunaan antibiotik sefalosforin yang merupakan kelas dari beta laktam relatif banyak digunakan dikarenakan kemungkinan terjadinya alergi yang kecil, memiliki efek samping yang rendah dah merupakan antibiotik berspektrum luas sehingga cocok 
digukanan untuk pemberian pada pasien ulkus diabetikum yang memiliki jenis bakteri Enterobacter sp. Pada penggunaan golongan kuinolon berkhasiat bakterisid pada fase pertumbuhan bakteri gram negatif, dengan menghambat enzim DNA gyrase bakteri sehingga menghambat sintesa DNA. Biasanya digunakan untuk infeksi kulit dan jaringan kulit. Pada penggunaan metronidazol yang termasuk dalam golongan amubisid digunakan karena sangat baik untuk bakteri anaerob. Bakteri jenis ini biasanya hidup pada luka tertututp seperti pada ulkus kaki diabetikum yang biasanya sudah terdapat nanah. Pemberian meronidazol juga digunakan untuk menjaga pasien dari infeksi kuman amoeba. Pada penggunaan golongan aminoglikosida, penggunaan diharapkan dapat dengan cepat berpenetrasi pada dinding bakteri dan mengikat pada ribosom dalam sel. Biasanya digunakan untuk menekan infeksi bakteri Pseudomonas sp. Pada penggunaan antibiotik secara kombinasi diharapkan ampuh untuk menghambat dan mengobati infeksi yang terjadi pada jaringan kulit oleh beberapa jenis bakteri tersebut. Kombinasi dilakukan berdasarkan hasil kultur bakteri untuk melihat apakah ada respon resistensi pada pemberian antibiotik tunggal.

Berdasarkan hasil penelitian ini, para dokter cenderung meresepkan antibiotik lebih banyak dan umumnya dari jenis antibiotik yang berspektrum luas (seftriakson). Hal ini mungkin dikarenakan para dokter lebih memiliki ketakutan akan timbulnya infeksi maupun resistensi pasien yang dirawat di rumah sakit lebih lama.

Tabel 3. Length of Stay Pasien rawat inap ulkus diabetikum di Rumah Sakit Samarinda Medika Citra

\begin{tabular}{cccc}
\hline No & Length of Stay & Jumlah & Presentase (\%) \\
\hline 1 & $2-3$ hari & 20 & $33,9 \%$ \\
2 & $4-5$ hari & 29 & $49.1 \%$ \\
3 & $6-7$ hari & 8 & $13,5 \%$ \\
4 & $>8$ hari & 2 & $3.5 \%$ \\
\hline
\end{tabular}

Tabel 4. Jumlah Hari Rawat Pasien

\begin{tabular}{cccc}
\hline Bulan & N & LOS (hari) & Rata-rata (hari) \\
\hline Januari & 3 & 10 & 3,33 \\
Februari & 9 & 42 & 4,66 \\
Maret & 4 & 13 & 3,25 \\
April & 3 & 12 & 4 \\
Mei & 6 & 34 & 5,66 \\
Juni & 7 & 37 & 5,28 \\
Juli & 2 & 6 & 3 \\
Agustus & 5 & 27 & 5,4 \\
September & 5 & 25 & 5 \\
Oktober & 3 & 9 & 3 \\
November & 8 & 45 & 5,62 \\
Desember & 4 & 16 & 4 \\
Jumlah & 59 & $\mathbf{2 7 6}$ & 52.2 \\
Rata-rata & 4,91 & 23 & 4,37 \\
\hline
\end{tabular}


Lama perawatan pasien berkisar antara 2-15 hari dengan rerata 4,37 hari. Rincian hasil lama hari rawat pasien yang sesuai standar adalah 2-3 hari (20 pasien; 33,9\%), 4-5 hari (29 pasien; 49,1\%). Adapun dalam penelitian ini, lama rawat inap pasien dengan kategori 6-7 hari dan $\geq 8$ hari dikarenakan pasien memiliki penyakit penyerta lain yang juga menjadi faktor yang menyebabkan lama hari rawat inap pasien lebih lama.

Data jumlah hari rawat diperlukan untuk menghitung penggunaan antibiotik pada pasien ulkus diabetikum dengan satuan DDD/ 100 patient-days. LOS (length of stay) merupakan lama hari rawat inap pasien terhitung sejak pasien masuk rumah sakit sampai dengan hari dimana pasien keluar dari rumah sakit. Pada tabel tersebut diatas menunjukkan bahwa dari 59 pasien ulkus diabetikum
Rumah Sakit Samarinda Medika Citra pada tahun 2017 memiliki rata-rata lama rawat inap selama 4,37 hari dan total jumlah hari rawat seluruh pasien adalah 276 hari.

Penilaian penggunaan antibiotik secara kuantitas dilakukan dengan cara menghitung DDD (Defned Daily Doses) per 100 hari rawat yang telah direkomendasikan oleh WHO. Penilaian kuantitas penggunaan antibiotik dari 59 catatan medik yang masuk dalam penanganan di Rumah Sakit Samarinda Medika Citra didapat dari perhitungan DDD/100 hari rawat. Semakin kecil kuantitas antibiotik yang digunakan menunjukkan bahwa dokter lebih selektif dalam peresepan antibiotik sehingga lebih mendekati prinsip penggunaan antibiotik yang rasional.

Tabel 5. Hasil Perhitungan DDD/100 Patient-Days pada pasien Ulkus Diabetikum di Rumah Sakit Samarinda Medika Citra

\begin{tabular}{|c|c|c|c|c|c|}
\hline Antibiotik & $\begin{array}{c}\text { Total } \\
\text { penggunaan } \\
(\mathrm{g})\end{array}$ & $\begin{array}{l}\text { Nilai } \\
\text { Standar } \\
\text { DDD } \\
\text { WHO }(g)\end{array}$ & $\begin{array}{l}\text { TOTAL } \\
\text { LOS } \\
\text { semua } \\
\text { pasien }\end{array}$ & Perhitungan & $\begin{array}{l}\text { DDD/100 } \\
\text { Patient days }\end{array}$ \\
\hline $\begin{array}{l}\text { (Sefalosporin) } \\
\text { Ceftriaxone } \\
\text { J01DD04 }\end{array}$ & 176 & 2 & & $\begin{array}{l}176 / 2 \times \\
100 / 276\end{array}$ & 31,88 \\
\hline $\begin{array}{l}\text { (Amubisid) } \\
\text { Metronidazol } \\
\text { G01AF01 }\end{array}$ & 15 & 0,5 & & $\begin{array}{l}15 / 0,5 \mathrm{x} \\
100 / 276\end{array}$ & 10,87 \\
\hline $\begin{array}{l}\text { (Carbapenem) } \\
\text { Meropenom } \\
\text { J01DH02 }\end{array}$ & 39 & 2 & 276 & $\begin{array}{c}39 / 2 \times \\
100 / 276\end{array}$ & 7.06 \\
\hline $\begin{array}{l}\text { (Kuinolon) } \\
\text { Ciprofloxacin } \\
\text { J01MA02 }\end{array}$ & 14 & 1 & & $\begin{array}{c}14 / 1 \times \\
100 / 276\end{array}$ & 5,07 \\
\hline $\begin{array}{c}\text { (Sulbactam) } \\
\text { Cefoperazon } \\
\text { J01DD62 }\end{array}$ & 16 & 4 & & $\begin{array}{c}16 / 4 \times \\
100 / 276\end{array}$ & 1,45 \\
\hline $\begin{array}{c}\text { (Aminoglikosida) } \\
\text { Amikasin } \\
\text { J01GB06 }\end{array}$ & 4 & 1 & & $\begin{array}{c}4 / 1 \times \\
100 / 276\end{array}$ & 1,63 \\
\hline
\end{tabular}


Tabel 6. Profil DU 90\% pada pasien Ulkus Diabetikum di Rumah Sakit Samarinda Medika Citra

\begin{tabular}{|c|c|c|c|c|c|}
\hline No & Kode ATC & Antibiotik & $\begin{array}{c}\mathrm{DDD} / 100 \\
\text { Patient days }\end{array}$ & $\begin{array}{c}\text { Penggunaan } \\
(\%)\end{array}$ & $\begin{array}{l}\text { Segmen } \\
\text { DU }\end{array}$ \\
\hline 1 & J01DD04 & (Sefalosporin) & 31,88 & 68,60 & $90 \%$ \\
\hline 2 & G01AF01 & $\begin{array}{l}\text { Ceftriaxone } \\
\text { (Amubisid) } \\
\text { Metronidazol }\end{array}$ & 10,87 & 19,76 & \\
\hline 3 & J01DH02 & $\begin{array}{c}\text { (Carbapenem) } \\
\text { Meropenom }\end{array}$ & 7.06 & 7,28 & \\
\hline 4 & J01MA02 & $\begin{array}{c}\text { (Kuinolon) } \\
\text { Ciprofloxacin }\end{array}$ & 5,07 & 6,01 & \\
\hline 5 & J01GB06 & $\begin{array}{c}\text { (Aminoglikosida) } \\
\text { Amikasin }\end{array}$ & 1,63 & 2,79 & $10 \%$ \\
\hline 6 & J01DD62 & $\begin{array}{l}\text { (Sulbactam) } \\
\text { Cefoperazon }\end{array}$ & 1,45 & 1,57 & \\
\hline Jumlah & & & 52,86 & 100,00 & \\
\hline
\end{tabular}

Penilaian penggunaan antibiotik secara kuantitas dilakukan dengan cara menghitung DDD (Defned Daily Doses) per 100 hari rawat yang telah direkomendasikan oleh WHO. Penilaian kuantitas penggunaan antibiotik dari 59 catatan medik yang masuk dalam penanganan di Rumah Sakit Samarinda Medika Citra didapat dari perhitungan DDD/100 hari rawat. Semakin kecil kuantitas antibiotik yang digunakan menunjukkan bahwa dokter lebih selektif dalam peresepan antibiotik sehingga lebih mendekati prinsip penggunaan antibiotik yang rasional.

Dalam penelitian ini didapatkan 15 variasi penggunaan antibiotik yang termasuk dalam penanganan di Rumah Sakit Samarinda Medika Citra dengan total 52,86 DDD/100 hari rawat. Hal ini dapat diartikan bahwa di antara 100 pasien yang dirawat inap terdapat sekitar 18 pasien yang mendapatkan 1 DDD obat golongan antibiotik. Penggunaan antibiotik terbesar adalah seftriakson sebesar 31,88 DDD/100 hari rawat, diikuti dengan metronidazol yang sebesar 10,87 DDD/100 hari rawat.

Terdapat 15 jenis antibiotik yang dikonsumsi pada pasien ulkus diabetikum pada periode Januari-Desember tahun 2017 dengan 4 jenis antibiotik yang masuk ke dalam segmen DU 90\% penggunaan terbanyak yaitu seftriakson, metronidazol, meropenem dan siprofloksasin. Banyaknya variasi jenis antibiotik menyebabkan rentannya insiden resistensi antibiotik dan meningkatkan peluang munculnya resistensi terhadap antibiotik yang digunakan.

Berdasarkan hasil penelitian ini, para dokter cenderung meresepkan antibiotik lebih banyak dan umumnya dari jenis antibiotik yang berspektrum luas (seftriakson). Hal ini mungkin dikarenakan para dokter lebih memiliki ketakutan akan timbulnya infeksi baik dari luka operasi maupun kontaminasi pasien yang dirawat di rumah sakit lebih lama. Dengan adanya perhitungan DDD/100 pasien, diharapkan penggunaan antibiotik di ruangan atau bangsal tertentu dapat dibandingkan dengan ruangan atau bangsal lain, bahkan antar rumah sakit atau antar negara sehingga dapat meningkatkan kualitas penggunaan antibiotik.

Penelitian ini memiliki beberapa keterbatasan, diantaranya jumlah sampel 
tidak mencakup seluruh pasien yang masuk dalam penanganan di Rumah Sakit Medika Citra pada periode januari sampai Desember 2017 dan hanya dapat diambil sejumlah sampel yang dianggap dapat mewakili. Metode pendekatan yang digunakan yaitu retrospektif dimana metode ini memiliki kelemahan pada penulisan medik yang tidak lengkap.

\section{KESIMPULAN}

Pada analisa kuantitatif jumlah keseluruhan DDD/100 patient-days didapatkan hasil Ceftriaxone sebesar 31,88 DDD/100 hari rawat, diikuti dengan metronidazol sebesar 10,87 DDD/100 hari rawat, meropenem sebesar 7,06 DDD/100 hari rawat, ciprofloxacin 5,07 DDD/100 hari rawat, Amikacin $1.63 \mathrm{DDD} / 100$ hari rawat dan Sefoperazone sebesar 1,45 DDD/100 hari rawat. Nilai tertinggi terdapat pada Ceftriaxone dengan nilai DDD/100 patient-days $=31,88$ dan terendah adalah Cefoperazondari dengan nilai DDD/100 patient-days $=1,45$. Dengan 3 jenis antibiotik yang masuk ke dalam segmen DU $90 \%$ penggunaan terbanyak yaitu seftriakson $68,60 \%$, metronidazol $19,76 \%$, dan meropenem 7,28\%. dan Co[rofloxacin $6,01 \%$. Hal ini menunjukkan bahwa kuantitas antibiotik yang digunakan tidak menunjukkan prinsip penggunaan antibiotik yang rasional.

\section{DAFTAR PUSTAKA}

[1] Bergman. (1998). Drug utilization 90\% - a simple method assessing the quality of drug prescribing.

[2] Brahma Marak and Wahlang. (2012). Rational Use of Drug and Irrational Drug Combination. The Internet Journal of Pharmacology, 10.

[3] Brunton et all. (2006). Goodman \& Gilman: Manual Farmakologi dan Terapi. Jakarta: Penerbit Buku Kedokteran.

[4] Driver, V.,R., Fabbi, M., Lavery, L., A., Gibbons, G. 2010. The costs of diabetic foot: the economic case for the limb salvage team. J Am Podiatr Med Assoc.;100(5):335-41.

[5] Gunawan, Sulistia G., Rianto, S., Nafrialdi, E. (2009). Farmakologi dan Terapi. Jakarta: Departemen Farmakologi dan Terapeutik Fakultas Kedokteran Universitas Indonesia.

[6] Hardman dan Limbird. (2008). Goodman \& Gilman Dasar Farmakologi Terapi Volume 2 (Edisi 10). Jakarta: EGC Penerbit Buku Kedokteran.

[7] Health Organization. Guidelines for ATC classification and DDD assignment 2016. The effects of brief mindfulness intervention on acute pain experience: An examination of individual difference (Vol. 1).

[8] Huang, E.S., Basu, A., O'Grady, M., Capreta, J.C. 2009. Projecting the Future Diabetes Population Size and Related Costs for the U.S. Diabetes Care, 32:2225-9.

[9] Kementrian Kesehatan Republik Indonesia. (2011b). Peraturan Menteri Kesehatan Republik Indonesia Nomor: 2406/MENKES/ PER/XII/2011. Jakarta: Kementrian Kesehatan Republik Indonesia.

[10] Kirsner, R.S., Warriner,R., Michela, M., Stasik, L., Freeman, K. 2010. Advanced Biological Therapies for Diabetic Foot Ulcers. Arch Dermatol.;146(8):857-62.

[11]Lobmann, R., Schultz, G., Lehnert, H. 2005. Proteases and Diabetic Foot Syndrome: Mechanisms and Therapeutic Implications. Diabetes care, 28(2):462-71.

[12]Pusat Data dan Informasi Persi. Available from http://www.pdpersi.co.id/conten/m_n ews. Diakses pada Februari 2018.

[13]Riset Kesehatan Dasar (Riskesdas) 2007. Laporan Badan Penelitian dan Pengembangan Kesehatan Departemen Kesehatan, Republik Indonesia. 
[14] Stockley, I.H. (2008). Drug Interactions, 8th edition, University of Nottigham Medical School. Pharmaceutical Press: London, 10311034.

[15] Tjay dan Rahardja. (2007). ObatObat Penting: Khasiat, Penggunaan, dan Efek-Efek Sampingnya. Jakarta: Media Komputindo Kelompok Kompas - Gramedia.

[16] Tripathi, K. D. (2009). Essentials of Medical Pharmacology. India: Kash production. 231-246.

[17]Utami, E. R. (2002). antibiotika, resistensi, dan rasionalitas terapi, 124-138.
[18] Van Baal, J.G. 2004. Surgical treatment of the Infected Diabetic Foot. Clinical Infectious Diseases, 39: S 123-8.

[19]Weck, M., Slesaczeck, T., Paetzold, H., Muench, D., Nanning, T., von Gagern, G., Brechow, A., Dietrich, U., Holfert, M., Bornstein,S., Barthel, A.,Thomas, A., Koehler, C., Hanefeld, M. 2013. Structured health care for subjects with diabetic foot ulcers results in a reduction of major amputation rates. Cardiovascular Diabetology 2013, 12:45.

[20] Whittem, T., \& Gaon, D. (1998). Principles of Antimicrobial Therapy. Veterinary Clinics of North America: Small Animal Practice, 28(2), 197-213. 